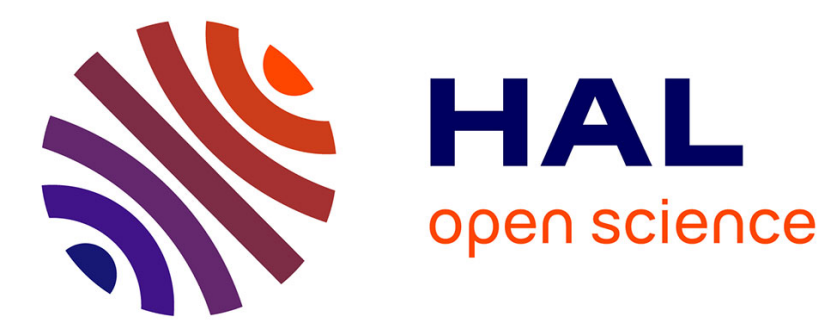

\title{
Cross-border mobility in Nogales since Trump's election
}

Pierre-Alexandre Beylier, Clea Fortuné

\section{To cite this version:}

Pierre-Alexandre Beylier, Clea Fortuné. Cross-border mobility in Nogales since Trump's election. Journal of Borderlands Studies, 2020. hal-03132412

\section{HAL Id: hal-03132412 \\ https://hal.science/hal-03132412}

Submitted on 5 Feb 2021

HAL is a multi-disciplinary open access archive for the deposit and dissemination of scientific research documents, whether they are published or not. The documents may come from teaching and research institutions in France or abroad, or from public or private research centers.
L'archive ouverte pluridisciplinaire HAL, est destinée au dépôt et à la diffusion de documents scientifiques de niveau recherche, publiés ou non, émanant des établissements d'enseignement et de recherche français ou étrangers, des laboratoires publics ou privés. 


\title{
Cross-border mobility in Nogales since Trump's election
}

\author{
Pierre-Alexandre Beylier, Associate Professor, Grenoble-Alpes University, ILCEA4 \\ Cléa Fortuné, PhD Student, Sorbonne Nouvelle University, CREW
}

Abstract: Building upon previous research on mobility, our study applies the concept of motility as developed by Kaufmann to border towns. This paper seeks to extend our knowledge on cross-border mobility under the Trump presidency by analyzing cross-border practices at the Mexico/US border, in the border towns of Nogales, Arizona and Sonora. The results of the survey lead us to conclude that though the border is present in the residents' daily lives, the dynamics that shape the border are changing. Cross-border mobility is reorganized locally in a context of rebordering and increased border surveillance.

Keywords: cross-border mobility, Nogales, motility, Mexico/US border, border town, twin town

\section{Introduction}

Mobility is generally described in geographical terms as a "crossing or a displacement in space" (Kaufmann 2014:9, Levy Lussault 2013:677). But it is more than just that. Mobility also has to do with flows. In the 1920s, it was conceptualized as opposed to social mobility in order to focus on the things and the people who were moving, following a systemic approach (Lannoy in Kaufmann 2014:43). Mobility also works hand in hand with (social) change (Bassand 1980) - whether it concerns a change in role, a change in lifestyle, or a change in state (Kaufmann 2014:41). Therefore, in spite of its opposition with social mobility, spatial mobility inherently has a social dimension. Besides, mobility creates links between the places we go to and it also allows people to gather (Bierlaire et al 2017:1). In other words, it structures territories by bringing spaces and people together.

Most of the seminal literature that deals with mobility and urban mobility often places its analyses within the framework of cities or metropolitan areas and they seldom analyze the concept of mobility in the specific context of border towns/cities (Kaufmann 2017, Montulet 2005, Kaufmann 2014). When such a thing as an international border runs across or near a city, it can be interesting to examine the impact it has on the mobility of border residents insofar as a border can be first and foremost a "discontinuity in space" (Gay 2004:70), a "separation line", a limit between two countries and two nations (Amilhat-Szary 2012:20, Pradeau 1994:5, Foucher 1991:86, Habla 2005:26). It can be even more interesting when a border town has a counterpart across the line as in the case of twin cities - "urban centers [that] straddle an international boundary and are economically and socially united within a single functional living space (Herzog 1990:1) - especially when it comes to mobility being examined in relation with the "discovery" or the "contact" of the other. It makes such an approach even more relevant in the context of border towns. Besides, while most studies focus on immigration, mobility can help us have a better understanding of the dynamics that shape the border in terms of movement because it encompasses more dimensions. (Heyman in Tapia 2017).

Some traditional patterns of mobility along the Mexico/US border are well documented. Authors point out the North-South flow of Americans purchasing some cheap goods and services on the Mexican side (Dear 2005:308), a part of one-day tourism (Arreola 1999), while South-North flows are more diverse with Mexicans crossing to buy American products they cannot find in Mexico (Goldberg 2008:298, Revel-Mouroz 1980:229), but also people commuting to work in the US (Revel-Mouroz 1980:229, McGuire 2013:467, Tréguer 1995:528) and children crossing the border to go to school (Fernandez 2003). These flows allow border towns to sustain a variety of cross-border links that shape their relations, contributing to their specificity and creating what Revel Mouroz calls some kind of "dissymmetrical interdependence" between border towns (Revel Mouroz 1980).

However, most studies only focus on one type of mobility: commuting (Kathryn Kopinak 2013, Herzog 1990, Cobb 1989), "consumer mobility" (Van der Velde 2010, Sullivan 2012, Baruca 2013), or medical tourism (Lapeyrouse 2014, Oberle 2004, Arreola 2004, Judkins 2007, Miller 2010), leaving aside other categories of crossers such as people who cross to visit friends and families or for other reasons. Yet, these links are part of the social fabric that constitute the very "functional ties" (Herzog 1990:1) or the "functional organization" (Foucher 1991:421, Vanneph 1995 (a):4, Vanneph 1995 (b):249, Macias 2007:97, Gay 2004:70) that bind twin towns together and that make their specificities. More specifically, this paper will examine mobility focusing on a case study: the twin cities of Nogales, Arizona/Nogales, Sonora. While most studies dwell on "big border towns" (Tijuana/San Diego, Ciudad Juarez/El Paso), having a look at medium-sized twin towns can bring additional knowledge of how twin towns function together, through the lens of border residents. Indeed, mobility constitutes a part of what Jańczak calls the "social base for [town] twinning" that he defines as the interactions that structure twin towns and make their specificity, whether they are "commercial contacts" and other cross- 
border activities or "non-commercial contacts" that have to do with "cross-border identity" and the presence of a culture that straddles the border (Jańczak 2017:488). Jańczak defines this model for European twin towns but it can be applied to the similar phenomenon, present along the Mexico/US border. Therefore, this paper aims at studying all kinds of mobility to offer a more comprehensive understanding of the different types of bordercrossers and to analyze how mobility shapes and structures border twin towns.

Founded in 1880 when a railway connection with Mexico was about to be built, Nogales, AZ saw the creation of its sister city of Nogales, SO 4 years later (Dear 2013:39). In the middle of the Sonoran Desert, they are home to 269, 588 people combined - 20, 188 for Nogales, AZ (US Census Bureau 2019) and 249, 400 for Nogales, SO (Citypopulation 2019). Nogales is known as “America's gateway for fresh produce" (Bruce Bracker 2019) and, more generally, in terms of trade volume, it is the $7^{\text {th }}$ busiest border crossing along the Mexico/US border (US Trade Numbers 2019). Nogales, SO, is also known for the dynamism of cross-border tourism since it used to be "one of the most successful tourist destinations on the entire Mexico/US international boundary" (Arreola et al 1999:23). However, in the last three decades, the twin cities experienced a tremendous change as a result of border enforcement. Before the 1990s, the border was a mere chain-link fence that ran across Ambos Nogales and that people could cross easily. Afterwards, it experienced a gradual fortification process: in 1996, the chainlink fence was replaced with a green steel wall made of landing mats before the construction of a real barrier $-\mathrm{a}$ "bollard-steel wall" - in 2011 as a result of the adoption of the Secure Fence Act of 2006 (McGuire 2013:467). Those towns also represent a specific spatial configuration: they are "twin towns". Not only do they depend on the border for their very existence as any other border towns but are also the manifestation of a phenomenon of "urban duplication" (Buursink 2001: 8). In other words, they are "binational cities" that are adjacent and connected (Buursink 2001). Their specificity lies in the links that shape them and that contribute to their "functional organization" as noted above. These links pertain to interdependence as suggested by Martinez who defines them as "centers of international dependence" (Martinez 1990) as well as to cooperation and interaction as emphasized by Gangster et al (Gangster 2016). Other authors emphasize their "feeling of mutual belonging" as another defining link binding twin cities together (Jańczak 2016:479).

The aim of this paper is to reflect on the impact that this "rebordering" process (Podescu 2012, Andreas 2003) has had on cross-border mobility. The authors want to look at how the presidency of Donald Trump and his antiimmigration rhetoric has shaped cross-border mobility and more generally how heightened security measures have impacted cross-border travel. In other words, have they hampered the daily crossing habits and interactions of border town's residents? Have residents adapted to them? Ultimately, the goal of this paper is to analyze cross-border mobility in order to see what this concept can teach us about the links that define twin towns and how they "function together". But this is not just a one-way relationship. Indeed, according to Kaufmann, it is as important to analyze how mobility can shape cities - in our case, border cities and their specificities - as to examine how these cities - and their surrounding territories - shape mobility (Kaufmann 2014:20). Applying this two-lensed approach to mobility can nourish our understanding of border towns and more specifically of twin towns/cities.

The paper is organized as follows. In the following section we present the theoretical background based on Kaufmann's analysis of mobility. Then we provide a description of the methodology and data used to conduct the survey. We then analyze the results to identify patterns of cross-border mobility at the Mexico/US border. A conclusion is presented in the next section.

\section{Theory: What is mobility?}

To begin with, one can define mobility in a very general way, using Kaufmann's definition: "spatial mobility refers to geographic displacement, the movement of an entity from an origin to a destination along a specific trajectory that can be described in terms of space and time" (Kaufmann 2004:746). However, as emphasized in the introduction, such an approach to mobility is restrictive and limited for the purpose of a scientific analysis. To better understand mobility, Schuler highlights four different types of mobility, according to two variables: the length of the journey - short term or long term - and the distance of the journey - inside or outside a living area. (Schuler 1997) [Table 1 near here].

To refine Schuler's typology, one could also cross it with Macias' who distinguishes tourists, who spend more than 24 hours across the border, and excursionists who are day-trippers (Macias 2007:91). This paper will only focus on "short term mobility" (excursionists), while trying to enrich these categories. Besides, in the case of a border, this can lead us to wonder how these flows define a "living area". In other words, how does the border bring a community together and do these individual flows impart some kind of specificity to border towns? Tapia conceptualized this question saying that the interactions produced by cross-border mobility turn a border region into a cross-border region, thus contributing to regional/local integration, a phenomenon she calls 
tansfrontericidad (transborderity) (Tapia 2017). Cross-border mobility can therefore be considered as a factor of integration.

However, mobility it is not just about the fact of moving from one place to another but it also concerns "the conditions of this act of moving" (Baud 2013). As a consequence, to better grasp this phenomenon, one can use Kaufmann's concept of "motility" that rather concerns "potential movement" (Kaufmann et al 2004:749) : "the capacity of entities (...) to be mobile in social and geographic space, or as the way in which entities access and appropriate the capacity for socio-spatial mobility according to their circumstances" (Kaufmann et al 2004:750). But this ability of being mobile only constitutes one pole that structures mobility. A second one is also present: "the welcoming power of a territory" (Kaufmann 2014:22). However, we cannot help but notice that, in border regions, regions that are intersected by an international border, this dichotomy is complicated by the presence of the border that inserts a third force, a force that is ambivalent - at the same time a dividing line and a meeting point (Pradeau 1994:5). Therefore, it can be interesting to analyze the impact the border has on mobility. In other words, if we go back to the "conditions of this act of moving", we can wonder if a border facilitates crossborder-mobility through the differentials it induces or if it hampers it because of border regimes that could constitute an obstacle. This second dimension constitutes one of the flaws that Kaufmann identifies in the study of spatial mobility and that he calls "the territorial constraints for the movement of goods or people" (Kaufmann 2004:752). It is even more relevant in the context of countries that are experiencing a "rebordering" process as is the case of the U.S. and Mexico.

In order to have a better understanding of cross-border mobility, the authors propose to use Kaufmann's theoretical model of "motility" that he articulates around three pillars. The first one, access, concerns the presence of infrastructure and transportation systems, the socio-economic position of people, and the spatial distribution of the population. The second one, competence, has to do with "physical abilities" but also "acquired skills" such as regulations and documentation, and "organizational skills". Finally, the third pillar, appropriation: how people "consider, deem appropriate and select different options". All three dimensions are interdependent (Kaufmann 2004:750) and one could add that they are shaped by a fourth pillar, representations: how people picture and imagine space, their journey, and, in border regions, which representations they have of the border. This approach is not new. Other authors have already analyzed how perceptions and representations affect cross-border practices (Jensen 2011:255, Di Méo 2009, Considère and Leloup 2017:55). This general model can be refined by a complementary model that Kaufmann et al defined in order to analyze motility thoroughly through three lenses. First, he identifies the range of possibilities, which pertains to the transportation networks - their efficiency and availability -, the different spatial configurations - in the case of a border town, this dimension is more than relevant -, the state of the labor market and the laws regulating human activities whether it is immigration, family policy, housing benefits and so on. The second lens concerns each individual's ability to move in the geographical, economic and social spaces. This second lens is linked to the first one: how an individual makes his or hers the range of possibilities in order to move. He emphasizes the concept of "intentionality". The third dimension is the displacement itself, the act of moving. These three dimensions are interdependent and this model helps analyze the way they interact to form the motility project (Kaufmann et al 2015: 13-14). Bearing these lenses in mind in analyzing cross-border mobility seems relevant.

\section{Methodology}

To get insights in cross-border mobility, the authors conducted a survey in Nogales, AZ and Nogales, SO in April 2019. The sampling procedure targeted participants in the city centers, not more than two miles away from the Port of Entry (PoE). On the U.S. side, the interviewees were chosen randomly. As for the Mexican side, the initial respondents were chosen randomly in the streets of the touristic area, followed by a snowball effect as respondents took us to other respondents they knew. People were interviewed, based on "participation-while interviewing" (Sheller and Ury 2006: 218), in various aspects of their lives: doing their shopping, in the workplace, relaxing in parks, waiting for the bus, going to the dentist, etc. The answers were recorded on paper and on smartphones. Data of 123 participants was collected, 76 on the U.S. side, 47 on the Mexican side. The survey included seven ended-questions with pre-established answers involving gender, age, frequency of border crossing, modes of transportation, being a member (or not) of the Trusted Travelers Programs, distance of the living place from the border and reasons for crossing the border. It also included two open questions with no preestablished answers, leaving the respondents to answer with their own words, including place of residence and the impact (or not) of Donald Trump's election on their border-crossing habits (Figure 6 near here). The goal was to identify potential factors that could help us point out trends regarding cross-border mobility in Nogales.

As the survey was conducted among people leading their daily life activities in both border towns, the authors had considered the difficulty of stopping people to answer the survey as it could be time-consuming for them or deemed suspicious, all the more so in a context of anti-immigration rhetoric and security buildup. However, if 
the respondents were approachable and open to answer the questions, the difficulty we had not expected was the language barrier in Nogales, AZ. Indeed, the surveys for the U.S. side had been prepared in English and the authors approached the respondents with English greetings. As a significant number told us that they did not speak English (52 respondents) and started to walk away, we then had to adapt very quickly and conduct the survey in Spanish. As for Nogales, SO the authors decided to conduct the survey in the tourist area, about four blocks away from the border. First, because it is where the curios shops, the physicians and drug stores are - and where U.S. tourists go to -, and thus where we would meet the most respondents. Second, because this area is deemed the safest for tourists.

As we conducted the surveys with a respondent, he/she would take us to another respondent that they knew who would answer our questions. On the Mexican side, this pattern repeated itself several times, so much so that after two hours of survey, even the residents we had not interviewed knew who we were and were greeting us. We started to attract attention, and as we decided to take a break and were about to cross a high traffic street, a car with tinted windows suddenly stopped in front of us. The man rolled down his window and asked us several questions about what we were doing in Nogales, where we came from, and if we were from Russia. As he was insistent, we pretended we did not speak Spanish and walked away. We then decided to stop the survey so as not to attract more attention, in a context of increased violence in Mexican border towns. Indeed, after the migrant caravan that had headed towards the U.S. in November 2018, the number of migrants in Mexican northern border towns increased, in congruence with extortion and violence that they face from the organized crime who pick them up at bus stations and in the streets (Agren 2019). We assume that because of the fair complexion of our skin, we had been taken for Russian asylum seekers who increasingly wait in Mexican border towns to cross to the U.S. (Silva 2019). Moreover, we had been told to be careful because of the recent kidnappings of tourists in the city. Indeed, a few days before the authors conducted the survey, a U.S. couple aged 38 and 40 had been kidnapped and held hostages in Nogales, SO for a ransom. A travel warning had been issued in early April 2019 "urging U.S. citizens to reconsider travel to Sonora because of criminal activity in the state" (Carranza 2019).

Despite this event that made us stop the survey in Mexico, we stopped the study because we had reached the principle of saturation, defined by Glaser and Strauss as follows: "Saturation means that no additional data are being found whereby the sociologist can develop properties of the category. As he sees similar instances over and over again, the researcher becomes empirically confident that a category is saturated" (Glaser and Strauss 1967:61). Indeed, the respondents' answers had started to be redundant, not providing new information to the study. Overall, we interviewed 61 men and 62 women of all age ranges: $8 \%$ under $18,31 \%$ between 18 and 35 , $19 \%$ between 35 and 50, 24\% between 50 and 65 and $18 \%$ over 65 . The results of the survey will be analyzed in the following section.

\section{Results}

\section{Frequency and modes of border-crossing: general findings}

Frequency and modes of border-crossing are the first parameters to study to get a general understanding of crossborder mobility along the Mexico/U.S. border. This is what Kaufmann identifies as the first pillar, access. It is the "range of possible mobilities according to place, time and other contextual constraints" (Kaufmann 2004:750). In a time of rebordering and anti-Mexican rhetoric where Ambos Nogales are separated by a fence and technological devices (McGuire 2013:467), we wondered how often people crossed the border and how. As Herzog explains, "U.S. and Mexican urban centers straddle an international boundary and are economically and socially united within a single functional living space" where "one finds intricate networks of communication and interaction" (Herzog 1990:1). The goal of this paper is to wonder whether Nogales is such a living place structured by cross-border interactions and if so, of what kinds.

To the questions "Do you cross the border?" and "How often do you cross the border?", the respondents gave a diverse portrait of mobility. Among the 123 respondents, 108 said that they cross the border. Overall there are two categories, frequent crossers and occasional crossers. A majority of people are frequent crossers, meaning that they cross several times per week $(21 \%)$, several times per day $(14 \%)$, once a week $(11 \%)$, and several times per month $(9 \%)$. As for the occasional crossers, they cross several times per year $(15 \%)$, once a month $(12 \%)$, once a year (3\%). We also met respondents who were crossing the border for the first time (3\%). Only $12 \%$ said they never cross the border and the reasons why will be analyzed below. Thus, even though the frequency of border crossing varies, Nogales is an active border and the location of countless interactions [Figure 1 near here].

In order to cross the border, the respondents need to have access to it. This "access is constrained by options that refer to the entire range of means of transportation and communication available, and the entire range of services and equipment accessible at a given time" (Kaufmann 2004:750). The first means available in Nogales are the three PoEs (Mariposa that handles commercial traffic, Morley Gate that handles pedestrian crossings and 
Deconcini that handles pedestrian and vehicle crossings) that border crossers use to go to the other side. They allow them to cross by foot, by car or by bike. To the question "How do you cross?", 67\% said they cross by foot, $19 \%$ cross by car, $11 \%$ use both means of transportations, $2 \%$ use the bike, and $1 \%$ did not answer. Thus, it is clear that border-crossers mainly cross by foot, which is reflected in the numbers of crossings according to the Bureau of Transportation Statistics. Indeed, between 2017 and 2018, there was a decrease in personal vehicle passenger crossings that dropped from 7.6 million to 7.1 million, for the benefit of pedestrian crossings that increased from 3.3 million to 3.4 million (Arizona-Mexico Economic Indicators 2019). However, when we combine the two variables - frequency and modes - the gap between crossing by foot or by car tends to narrow the more the respondents cross. Indeed, among those who cross several times per week, $42 \%$ cross by foot and $31 \%$ cross by car. On the contrary, among the respondents who cross for the first time, $100 \%$ cross by foot. This can be explained by different factors. First, these respondents are not familiar with the border. Second, there is a range of services and equipment available, such as the numerous border parking lots on the U.S. side, at walking distance from the PoE, that makes it easy to park in Nogales, AZ to cross to Mexico by foot. And third, the respondents said that waiting times to cross the border by car were very long. However, the more the respondents cross, the more their activities span the border on both sides and the more they need their car both in Mexico and in the U.S. This will be further explored in the next section.

During the survey, the variable of being a member of a border-crossing facilitation program (or not), called Trusted Traveler Programs, was added. This is what Kaufmann identifies as the second pillar of motility, competence made of three aspects: physical ability, acquired skills and organizational skills. The Trusted Traveler Programs is part of the "acquired skills relating to rules and regulations of movement, e.g. licenses, permits, specific knowledge of the terrain or codes" (Kaufmann 2004:750). Among the respondents who cross, only $18 \%$ said they were members of the Trusted Traveler Programs and cross several times per day, per week, per month and per year. The majority (61\%) are SENTRI (Secure Electronic Network for Travelers Rapid Inspection) card-holders. This card operates at the southern border PoEs for vehicle crossings only. According to data available on the U.S. Government Accountability Office website, from 2009 to 2014, entries through lanes for SENTRI "increased from 5.9 million to 12.6 million vehicles" (GAO 2014). Another 33\% are part of the Trusted Traveler Programs as Global Entry card-holders. These cards operate at the border between the U.S. and Mexico but also between the U.S. and Canada. The members of these programs experience shorter wait times than regular travelers and CBP spends less time inspecting them at PoEs since they have already undergone a background check to become members, and because specific crossing lanes are designed for them (GAO 2014). In 2014, more than 3.3 million people enrolled in the Trusted Traveler Programs (DHS 2015).

It is important to mention that if not all the respondents have the acquired skills to be members of the Trusted Travelers Programs since it represents expenses (it costs \$122 USD for the SENTRI card and \$100 USD for the Global Entry card), not all the respondents have the first skill needed to cross, i.e. the physical ability or "the ability to transfer an entity from one place to another within given constraints" (Kaufmann 2004:750). Indeed, among the 15 respondents who never cross the border, 9 of them live in Nogales, SO and mentioned that it is because they have no documentation - it is expensive to get a passport and a visa - or because they had been deported from the U.S. to Mexico and could not apply for a visa anymore. This is the distinction that Martinez draws between "national fronterizos" who live at the border and who do not interact directly with it, and "transnational fronterizos" who cross the border and "maintain significant ties with the U.S. side" (Martinez 1990:80).

Overall, the border towns of Nogales are united through the diverse mobility of people. However, the rebordering process of the U.S.-Mexico border creates inequalities in mobility. As Pallitto and Heyman explain, "the amplified border security regime generates differential mobility effects, so that the ability of individuals to negotiate borders becomes unequal in certain respects" (Pallitto and Heyman 2008:315).

\section{Reasons for crossing}

The second parameter worth studying to have a better understanding of cross-border mobility concerns the reasons why people are crossing the Mexico/US border. It has to do with the third pillar Kaufmann identifies to define motility, which is appropriation, or in other words, how people "consider, deem appropriate and select different options". Analyzing the reasons that underlie cross-border mobility is directly linked with these "options".

To begin with, in absolute terms, the reasons our 123 interviewees gave for crossing the border are the following: 70 for leisure, 27 to visit friends and/or family members in the other country, 23 for medical reasons, 18 for work and 7 for school. If we add up the numbers, we are over 123 responses because the respondents were given the opportunity to give several responses. 
One can note that the main reason is "leisure" (more than half of the respondents), emphasizing activities such as going to restaurants, to bars, sightseeing and, more importantly shopping - 50 out of 70 gave shopping as one of the reasons for crossing (this number does not include medical shopping. This was counted separately in the category "medical reasons"). As mentioned above, this aspect of cross-border mobility is well-documented in the literature concerning the Mexico/U.S. border. Martinez calls them "binational consumers" (Martinez 1990:88). Even if Martinez only applied this term to Mexicans going shopping in the U.S., it can also be applied to Americans crossing the border for shopping purposes. They are Americans going to Mexico to buy exotic products and Mexicans going to the U.S. to purchase clothes, shoes or groceries that they cannot find on the Mexican side, and that are sometimes considered of better quality, a phenomenon that is present in many places along the border (Miller 1981:48) and more specifically in Nogales (Miller 1981:176). Besides, the geography of both cities is marked by this kind of activity. Indeed a number of gift shops (curios shops) can be found close to the international boundary in Nogales, SO and similarly, many well-established retail shops were built in Morley Avenue, a street that starts at the border and runs parallel with Grand Avenue, the street that goes to the downtown port of entry in Nogales, AZ to attract Mexican customers. This kind of cross-border shopping is well-documented, especially in Europe: Van der Velde highlights the positive impact a border could have in terms of "international differences" that drive people to the other country in order to shop (Van der Velde 2010:201). In our case, Nogales has been known for being very dynamic in terms of retail even if in the last decade, as a result of heightened security, the retail business is no longer as thriving as it used to be (Bracker 2019).

The other three activities, that are present in quasi-similar proportions, embody specific activities that are present in border towns: people visiting friends and family, medical tourism and commuters. First, people crossing to visit friends and families (27 people) testify to the social interactions that animate border towns and impart to them some kind of dynamism. In Ambos Nogales, like in most twin towns such as San Diego and Tijuana, communities are unified by family or friendly links with "lives [...] rooted in both sides of the border" (Dear 2013:101). This phenomenon is especially true among Hispanics as Lapeyrouse showed in a survey that highlighted what he called "familismo", some kind of "family cohesion" that, along with a "strong sense of pride", shapes social relations in border towns (Lapeyrouse 2012). In other words, the cities are linked by an integrated social fabric that makes their specificity and is a sign of the "binational dimension" of the city. Indeed, 94,2\% of the population of Nogales, AZ identifies as Hispanic/Latino (Quickfacts 2019).

The other most relevant category concerns "medical tourism" (23 people) (Judkins 2007:13). Again, this phenomenon is very much present along the Mexico/U.S. border (Macias 2001:77) given the fact that some procedures and some drugs are much cheaper on the Mexican side. The people we interviewed mostly went to Nogales, SO to get dental work done and to get prescription drugs due to price differentials. Research has shown that some drugs are 75\% cheaper in Mexican border town pharmacies than in American ones (Judkins 2007:20). Likewise, getting a tooth pulled out along with crowns and bridge works only costs $\$ 800$ in Mexico as opposed to between $\$ 3,000$ and $\$ 5,000$ in the U.S. (Miller 2010:3). Only one Mexican crossed to the U.S. for medical reasons in order to donate platelets. Another important reason for crossing the border is to go to work on the other side (18 people). Cross-border commuters that go either to the U.S. or to Mexico to work " travel each day much like other intra-urban commuters, yet their journey to work involves the crossing of an international boundary line" (Herzog 2011:2).

Finally, a last category of people crossed to go to school. Children living in Mexico are enrolled in U.S. schools. The 7 respondents were all met on the U.S. side, lived on the Mexican side, and 3 of them did not speak English. Goldberg argues that "school enrollment forms [in Nogales, AZ] show that $28 \%$ of students are born in Mexico" (Goldberg 2001).

All these phenomena - except for people crossing for school and for medical reasons - go in both directions and illustrate trends that are present all along the Mexico/U.S. border, making it a dynamic interface animated by different categories of people: excursionists and commuters that cross for different reasons.

Besides, one can also note that the people who cross the border come from different geographic origins. A majority of the people surveyed (63\%) come from the border town itself, from Ambos Nogales, or from the border region (7\%), up to 25 miles. However, some more distant crossers are also part of the sample: $20 \%$ of them come from towns/cities located between 25 and 100 miles and 9\% come from places over 100 miles from the border, such as New York, New Jersey, California in the United States and Sinaloa in Mexico. In other words, one third of the people questioned were from more remote places, having no or few personal ties with Nogales. These numbers allow us to identify two kinds of mobility. On the one hand, we have a kind of local 
mobility that evidences the community's local dynamism as well as some kind of local connectivity between the two twin towns. On the other hand, we have a more distant kind of mobility that testifies to the power of attraction of Nogales, that is due to its location on the border and that is made possible because of its integration in the North American transportation system. Nogales' integration in the North American transportation system brings us back to one of the pillars defined by Kaufmann: access (Kaufmann 2004: 750). Indeed, Nogales, AZ is linked to Tucson, which is 66 miles away, with Interstate 19, which then intersects Interstate 8 that goes to San Diego and Los Angeles and Interstate 10, that links Tucson to Phoenix to the west and El Paso to the East. As for Nogales, SO the city is connected to Sonora's capital city, Hermosillo, through Mexican Federal Highway 15 and to other border towns such as Sonoyta and Agua Prieta with Mexican Federal Highway 2 that runs 40 miles south and intersects Mexican Federal Highway 15 in Imuris. This well-developed transportation system is reinforced by the two PoEs, Grand Avenue/Morley PoE, that operates 24/7 and Mariposa PoE that is dedicated to trucks and located west of the city, as well as by the presence of parking lots in downtown Nogales for people who want to cross on foot. This infrastructure enhances Ambos Nogales' location at the border, making it a strategic crossroads, or gateway, for those wanting to cross the Mexico/US border. Not all border towns benefit from such infrastructure and, therefore, not all of them experience the same amount of cross-border mobility as is the case of San Luiz Colorado that is, in turns, less dynamic, especially when it comes to cross-border tourism (Arreola 1999:24) [Figure 2 near here].

When we analyze the distance parameter with the frequency parameter, one can note that, among those who cross daily, weekly and monthly, the respondents mainly live less than 2 miles away from the border, i.e. in the border towns of Nogales, Arizona and Sonora. However, among those who cross several times per year, no respondent lives close to the border. Indeed, 33\% live in a range from 2 to 25 miles, $44 \%$ between 25 and 100 miles away from the border and $36 \%$ more than 100 miles away from the border. Among those who never cross, $18 \%$ live in the border towns, less than 2 miles away from the border. These findings reinforce the idea that local mobility is marked by some kind of dynamism evidenced by the relatively high frequency at which local residents cross the border [Figure 3 near here].

To go further in our study, when we cross these two parameters - reasons for crossing and distance/origin - one can better understand how local and distant mobility function. First of all, most people crossing to visit friends and families are from Ambos Nogales (78\%). Only a minority is from more distant but still relatively close places $-11 \%$ from places located fewer than 25 miles away from the border and $11 \%$ from places between 25 and 100 miles. It shows how the community is rooted locally and how dynamic social ties are. Another factor that reinforces these local cross-border links has to do with the people who cross the border to go to school: $100 \%$ of them come from Nogales, SO. Finally, two thirds $(66 \%)$ of the people who cross for leisure also come from Ambos Nogales and only 50\% of commuters come from the border towns. Consequently, local mobility is at the same time diverse and well established in Nogales, marked by daily activities ranging from work, school, leisure and social interactions [Figure 4 near here].

When we look at semi-distant mobility, one specific category of border-crossers stands out: medical tourists. Indeed, a vast majority of them $(61 \%)$ come from semi-distant places - between 25 miles and 100 miles. In detail, 8 people come from Tucson, 5 from Green Valley, 4 from other towns in Arizona and one from California. These numbers show the regional power of attraction of the town as far as medical tourism is concerned, the border structuring this very specific economic activity and stimulating this kind of mobility. One can also note that, for this category of regional mobility, the other reasons are not significant (only $11 \%$ of commuters and $11 \%$ of people crossing to visit friends or family members come from these semi-distant places), except for one: leisure, $23 \%$ of them belonging to semi-distant mobility. The interviewees often said they coupled their coming to Nogales, SO for medical reasons, with more leisure-oriented activities such as going to the restaurant or shopping. Therefore, what can be considered as a very utilitarian activity - medical tourism also constitutes an opportunity for people living far away from the border to experience Mexico and discover what Mexico has to offer in terms of food and products thus making this kind of mobility a more "fun experience", with people taking advantage of different "exotic" things Mexico has to offer.

Finally, as far as distant mobility is concerned, a great majority of the people (70\%) who cross the border are commuters and those people who travel over 100 miles represent $28 \%$ of all commuters. However, it does not mean that they are daily commuters. As underscored above, most of them cross on a regular but not frequent basis, either once a month (36\%) or several times a year (36\%). These "long distance commuters" correspond to a new category of people that emerged in the last decades (Kaufmann 2014:55). Since they do not cross on a daily basis, they can be labeled as occasional crossers. 
Finally, when we match the reasons for crossing the border with the age category of the respondents, one can note interesting correlations. First, quite evidently, all people crossing to go to school are below 20 years old. Likewise, a great majority of the people commuting (94\%) are in working age $-39 \%$ between 18 and 25 years old, $22 \%$ between 35 and 50 and $33 \%$ between 50 and 65 . Quite instinctively, medical tourism mainly concerns people of a certain age: $26 \%$ of them are between 50 and 65 and $57 \%$ are over 65 . More interestingly, the majority of one age category - people between 18 and 35 - mostly cross the border to visit friends and family (48\%), which mirrors the demographic dynamism of Nogales whose median age is 33.7 (Arizona Demographics 2019). The age factor tells us that each demographic has a specific activity that underlies their mobility. In other words, in terms of appropriation, each age group appropriates the border differently, according to its own priorities related to age - especially when it comes to school, work or medical tourism. There is only one activity that all demographics share in similar proportions - between 19 and 29\%, except for underage people - that is leisure. It shows that beyond the priorities linked with each age group, an additional reason somehow links them and it mirrors the central role of the "amateur border" (Sands 2009:26), that is crossed for hobbies or "fun activities". This expression was used to depict the Canada/US border but can be applied to the Mexico/US border [Figure 5 near here].

The border is present in people's daily lives, they cross it from more or less remote places, more or less frequently and it is linked with some kind of hobby, a hobby that has to do with the specific activities and products that are made available by the fact of living close to a foreign country, which is made possible by the border.

\section{The impact of Trump's election}

The appropriation pillar was further developed in the survey through the study of the impact of President Trump's election on the cross-border mobility of people. Since 2016, Donald Trump has been committed to constructing a border wall between the United States and Mexico, a wall that already exists in many portions of the border such as between Ambos Nogales. In January 2017, he signed executive orders to hire 5,000 new Border Patrol agents and 10,000 more Immigration and Customs Enforcement officers vowing to beef up border security and crackdown on illegal immigration" (O'Toole 2019). This section thus studies the potential changes for border mobility under Trump's presidency thanks to the appropriation pillar. "Appropriation is shaped by needs, plans, aspirations and understandings of agents, and it relates to strategies, motives, values and habits" (Kaufmann et al. 2004:750). In the previous section, the respondents' needs, plans and aspirations were analyzed. In this section, we focus on how they negotiate cross-border mobility. In other words, what strategies, motives, values and habits do they adopt?

To the question "Has the election of Donald Trump altered your interaction with the border?", 47\% of the respondents answered negatively, 53\% answered positively. Those who answered positively were asked to develop the reasons why and this section focuses on their answers (all the words and sentences between inverted commas are the respondents' answers to the question "Why and in what ways did President Trump's election alter your interactions with the border?").

According to the survey, 41 respondents said their border-crossing habits were affected because it takes more time to cross the border from one side to the other, especially from Mexico to the U.S. since Donald Trump's election. One respondent explains in Spanish that "for workers like [them], it requires a lot of time to cross" (Para trabajadores como yo necesita mucho tiempo para cruzar). Because of the "long lines" and the "slowness" of the crossing process, border crossers have had to adopt new strategies to cross the border, such as getting in line earlier in the morning to avoid congestion and to get to the U.S. more quickly. In 2014, Customs and Border Protection (CBP) even developed an app that border-crossers can download on their smartphones, called "Border Wait Times", so that they can know how long it gets to cross to the U.S. before getting in line (U.S. Customs and Border Protection 2019).

The second main reason given by the respondents is that there is more control at the border. 14 respondents said that they were "asked more questions" such as "where are you going? What is the purpose of your trip? Where are you from?". They mentioned that "more technology is used" such as CBP "taking pictures", that there is "increased caution, more than before" (muchas mas cuidado que antes) and "stronger border measures", such as the barbed wire that was installed in December 2018 all along the U.S.-Mexico border. As Murià and Chavez explain, "crossers are constantly screened by cameras, license plate readers ... These technological devises capture crossing patterns" and they are "subjectively interpreted by ... border crossers themselves" (Murià and Chávez 2011:365). These factors help explain the longer wait times that the respondents experience when crossing the border. One respondent also argues that "moving personnel to other borders has added to the burden of monitoring people and vehicles entering the US". Indeed, CBP officers who are responsible for processing 
vehicles, pedestrians and trucks at the Mexico/US border have been redeployed - to Texas especially (Industry News 2019) - to assist Border Patrol agents in their work of apprehending undocumented immigrants. Along the U.S.-Mexico border, "545 officers ... have been redeployed so far". If "Arizona has had no officers pulled", they are however "not receiving the officers they usually get from elsewhere, so they are feeling the impact ... which is an 8\% cut into their normal workforce" (Industry News 2019). Besides, "the vast array of high-end technological devises, biometric cards, sensors and databases, seem to be combined with the visual discrimination agents conduct in their daily routines" (Murià and Chávez 2011:365), which is expressed by 8 respondents who share a feeling of increased racism. They explain that CBP is "more aggressive" and that "it makes it more difficult and uncomfortable when it comes to interacting with the U.S. Customs". However, as Grandin expounds, "the militarization of the southern border is a long-standing American tradition" (Grandin 2019). The rebordering process was emphasized in the wake of the 9/11 terrorist attacks when President George W. Bush passed the Secure Fence Act that allocated billions of dollars for the "virtual wall", i.e. "aerostat blimps, radar, helicopters, watchtowers, surveillance balloons", etc. (Grandin 2019). The security buildup continued under the Obama administration when "the Democratic Party would continue to fund ... border security programs that amounted to years of up-armoring the border in what was then referred to as a 'border surge" (Grandin 2019). Thus, the way the mobility of border-crossers is affected did not start with the Trump administration, though the impact is real by being "subjectively interpreted" by border-crossers themselves (Murià and Chávez 2011:365).

Another reason mentioned by 10 respondents is that the election of Donald Trump has been hurting businesses on the border. Because the border "is clogged up, it does damage on both sides", attracting "fewer tourists", "fewer snowbirds". One respondent says: "We have a real problem and it is called T.R.U.M.P". His repeated "threats of closing the border" have affected the economy of both border towns. As Van der Velde and Spierings explain, "mobility is seen as a precondition for economic growth" (Van der Velde and Spierings 2010:191). However, border-crossers have expressed that they "think twice before coming. If you come and cannot go back...". This makes reference to Donald Trump who closed the border in December 2018 at the San Diego/Tijuana PoE for five hours, when Central Americans were fleeing violence in their home countries and heading to the United States (Holpuch 2018). This created disruption for border communities. "The parallel situations have worried people who live near busy ports of entry such as the one between Nogales, Arizona, and Nogales, Mexico. US Customs and Border Patrol (CBP) has been conducting drills in Nogales similar to the ones that took place before San Ysidro was closed, and locals have warned CBP that a similar shutdown could have catastrophic consequences for the region" (Holpuch 2018), and especially economic consequences. As shown in the section above, shopping habits make the region economically integrated. As this respondent explains, border residents are "aware of the impact the administration's anti-immigration and anti-asylum seekers policy and rhetoric have had on this border town [Nogales, AZ]. The slowdown for people crossing has had a negative impact on the economy of both cities. Trade and commerce benefit from swift and efficient processing and inspection. Moving personnel to other borders has added to the burden of monitoring people and vehicles entering the U.S.”.

Since half of the respondents said that they were affected by Donald Trump's election and the other half said they were not, we decided to correlate their answers with the variable of the distance. In other words, are border crossers more or less affected if they live close to or far from the border? None of the respondents who live more than a hundred miles away from the border mention that their border-crossing habits were altered. On the contrary, the respondents who express an impact on their livelihoods because of the election of Donald Trump are the ones who live less than 2 miles away from the border (72\%) as well as those who live from 25 to 100 miles away from it (18\%) [Figure 4 near here]. This category of border-crossers who live far from the border do not have border habits contrary to those who live close to it and whose livelihoods are shaped by the border. They are not affected daily by the realities of life on the border since they only cross for work, contrary to border residents whose activities take place on both sides. Thus, if their cross-border mobility is hampered, it may affect border towns as a "functional living space" (Herzog 1990:1). Because of the many constraints experienced by the border crossers, new strategies will be adopted to maintain cross-border mobility that boosts the border towns' economies. One of them is already being discussed by city officials in Ambos Nogales, who are "meeting to work on a plan to shorten waiting times, provide shade and have water and bathroom facilities for those waiting on the Mexican side to cross into the U.S." (Montoya 2019).

Overall, this section concludes that "border enforcement and surveillance... reorganize the mobility of local populations whose livelihoods are defined by cross-border social and economic activities" (Chavez 2011: 355). The survey pointed to the impact of Donald Trump's election on the border residents' daily lives, however it should be mentioned that it is more his rhetoric about immigration, Mexicans and permeability of the border that affects border residents than his actions. Indeed, the lines to cross were already long under the previous 
administrations and security devices were already in place. What changed with the election of Donald Trump is the perception the respondents have of the border and thus their mobility practices. However, one resident claimed that if Donald Trump had an impact on cross-border mobility, it was "not enough to penetrate the crossborder cultural dynamic".

\section{Conclusion}

This paper has helped demonstrate that cross-border mobility in Ambos Nogales is diverse, dynamic and multiscalar. On the one hand, local mobility constitutes the fabric that binds the twin cities together, the base of their specificity and their dynamism, making them integrated and reinforcing the "paradigm of border twin towns as integration laboratories" (Jańczak 2013). This is illustrated through activities ranging from school, work, shopping, visits to friends and family. These activities embody the daily lives of the residents, i.e. cross-border lives, specific of the borderlanders that Martinez described in the 1990s (Martinez 1990:79) and who make the most of the three pillars: access, competence and appropriation. If access is impacted by the rebordering phenomenon by the wait times that are entailed at the border as a result of bolstered controls, it is the competence pillar that is impacted the most especially through the imposition of new requirements - with WHTI and the visas - that really deter people from crossing.

Cross-border mobility, through the specificities that we have highlighted in this paper, thus helps us define the borderlands, a social space that is under reconfiguration shedding new light on the thesis put forward by Sheller and Ury according to whom "mobilities thus entail distinct social spaces that orchestrate new forms of social life around such nodes", with the border constituting such a node (Sheller and Ury 2006:213)

Even if the securitization of the border has created an obstacle to individuals' ability to move and led to a reconfiguration of the border space in terms of the range of possibilities defined by Kaufman, individuals have adapted to this new paradigm in order to take advantage of the differentials created by the border that make cross-border travel relevant and important for them - through shopping activities, the labor market and so on. On the other hand, Nogales also constitutes a gateway that structures some kind of regional and national mobility. This kind of mobility is more occasional and gives access to Mexico for people who are working or looking for some cheaper medical treatment.

However, what mobility also highlights through this case study, and more generally at the Mexico/US border is a new form of "social inequality" (Kaufmann 2014:65). Borders are not the same for everyone (Amilhat-Szary 2015), they no longer function in an equal way and mobility, especially in Nogales, SO is impacted by the U.S. visa policy, with residents that just cannot cross the border. In other words, the border undermines the "hospitality of the territory" (Kaufmann 2014:174) or its "welcoming power" (Kaufmann 2014:22) by making it less attractive and more aggressive. Mobility thus appears as a resource and, as Skeggs suggests: "Mobility and control over mobility both reflect and reinforce power. Mobility is a resource to which not everyone has an equal relationship" (Skeggs, in Sheller and Ury 2006:211).

In all, it leads to the construction of two "areolary spaces", i.e. a static space that is embodied as a closed/fenced space, characterized by an inside and an outside (Kaufmann 2014:37), meaning that the border fence is becoming less and less porous to daily exchanges between two cities that used to function as a unified whole across a border that was more fluid, friendly and "open". The "paradigm of border town towns as integration laboratories" is thus jeopardized as the relationships between Ambos Nogales are hampered by increased security. However, this process has not been happening solely under D. Trump's presidency, whose impact on cross-border mobility is difficult to assess. The impact of the rebordering phenomenon has been felt in the long term and with Trump, only the climate at the border has changed, relations becoming tenser and controls more aggressive. It is a matter of perceptions and representations, the fourth pillar that could be added to Kaufmann's theory of motility: how people imagine the border region and how it affects their cross-border practices. In other words, how is mobility shaped by representations? This question of representations remains a topic to be tackled for future research.

\section{Acknowledgments}

We would like to acknowledge the University Sorbonne Nouvelle-Paris 3, University Grenoble Alpes and Borders in Globalization (BIG) for helping to finance this project. We would also like to specially thank Eric Royer for helping to carry out this research. His help during the surveys and his mastery of Spanish were very helpful.

\section{References}


Amilhat-Szary, Anne-Laure, «Frontières et conflits : une approche territoriale ». (Borders and Conflicts: a territorial Approach). In Bulletin de l'Association de géographes français, 89e année, 2012-1. Risques et conflits, sous la direction de Roland Pourtier et Srépane Rosière. pp. 18-33.

Amilhat-Szary, Anne-Laure, Qu'est-ce qu'une Frontière aujourd'hui ?, Paris, Presses Universitaires de France, 2015.

Andreas, Peter, and Biersteker, Thomas J, The Rebordering of North America: Integration and Exclusion in a New Security Context, New York, Routledge, 2003.

Arreola, Daniel D. and Madsden, Kenneth, "Variability of Tourist Attraction on an International Boundary: Sonora, Mexico Border Towns", Visions in Leisure and Business, Vol 17, Iss. 4, Winter 1999, pp 19-31.

Bassand, Michel and Brulhardt Marie-Claude, Mobilité spatiale, éd. Georgi, St-Saphorin, 1980.

Barruca, Arne, "Cross-border shopping: Mexican shoppers in the US and American shoppers in Mexico", International Journal of Consumer Studies, 37(4), July 2013.

Baud, Pascal et al, Dictionnaire de géographie, Paris, Hatier, 2013.

Bierlaire, Michel, Kaufmann, Vincent and Rérat, Patrick (dir.), La Mobilité en questions, Lausanne, Presses polytechniques et universitaires romandes, col. «Enjeux mondiaux », 2017.

Buursink, Jan, "The binational reality of border-crossing cities", The Binational City, GeoJournal 54, 2001, 719.

Cobb, Steven L., Molina David J. and Sokulsky Kariann, "The impact of maquiladoras on commuter flows in the Texas-Mexican Border", The Journal of Borderlands Studies, Vol 4, Issue 1, 1989, pp 71-88.

Considère, Sylvie and Leloup, Fabienne, «Comment interroger la frontière par les représentations sociales ? » in Considère, Sylvie and Perrin, Thomas, Frontières et représentations sociales : questions et perspectives méthodologiques, Paris, L’Harmattan, 2017.

Dear, Michael, Why Walls Won't Work - Repairing the US-Mexico Divide, Oxford, Oxford University Press, 2013.

Dear, Michael and Burridge, Andrew, "Cultural Integration and Hybridization at the United States-Mexico Borderlands", Cahiers de géographie du Québec, Conflits, Proximité, Coopération, Volume 49, Issue 138, décembre 2005.

Di Méo, Guy, «Patrimoine et territoire, une parenté conceptuelle », Espaces et Sociétés, n78, 1994, pp. 15-34.

Fernandez, Leticia, Amastae, Jon and Howard Cheryl, "Education and migration in a border city", The Journal of Borderlands Studies, Volume 18, Issue 2, Fall 2003, pp. 25-44.

Ganster Paul \& Collin, Kimberly, "Binational Cooperation and Twinning: A View from the US-Mexican Border, San Diego, California and Tijuana, Baja California", Journal of Borderlands Studies, 32-4, pp. 497-511.

Goldberg, Anne J., "Company Town, Border Town, Small Town: Transforming Place and Identities on the U.S.Mexico Border", Journal of the Southwest, Vol. 48, No 3, Autumn 2006, pp. 275-306.

Goldberg, Anne J., "Transnationalism and Borderlands: Concepts of Space on the U.S.-Mexico Border and $\begin{array}{lllll}\text { Beyond", } & \text { Estudios } & \text { fronterizos, } & \text { Vol } & 2(4),\end{array}$ 
http://www.scielo.org.mx/scielo.php?script=sci_arttext\&pid=S0187-69612001000200002\#nota> (accessed on August 10, 2019).

Habla M. E., «Vocabulaire de la Frontière », in H. Velasco-Graciet and C. Bouquet (éd.), Tropisme des frontières - Tome 1, Paris, L'Harmattan, 2005.

Herzog, Laurence, "Border commuter workers and transfrontier metropolitan structure along the United StatesMexico Border", The Journal of Borderlands Studies, Vol 5, Issue 2, 1990, pp. 1-20.

Jańczak, Jaroslaw, "Town Twinning in Europe. Understanding Manifestations and Strategies", The Journal of Borderlands Studies, Volume 32, 2017, Issue 4: Special Issue: Theorizing town twinning: Towards a global perspective, pp 477-495.

Jańczak, Jaroslaw, 'Revised Boundaries and Re-Frontierization Border Twin Towns in Central Europe', Revue d'études comparatives Est-Ouest, 2013/4 (n44), p. 53-92.

Jensen, Anne, "Mobility, Space and Power: On the Multiplicities of Seeing Mobility", Mobilities, 6:2, 2011, pp. 255-271.

Judkins, Gabriel, "Persistence of the U.S.-Mexico Border: Expansion of Medical-Tourism amid Trade Liberalization", Journal of Latin American Geography, 6 (2), 2007, pp. 11-32.

Kaufmann, Vincent, Max Bergman, Manfred and Joye, Dominique, "Motility: Mobility as Capital", International Journal of Urban and Regional Research, Volume 28.4, December 2004, pp 745-756.

Kaufmann, Vincent, Retour sur la Ville : Motilité et transformations urbaines, Lausanne, Presses Polytechniques et universitaires romandes, 2014.

Kaufmann, Vincent et al (dir.), Motilité et mobilité, mode d'emploi, Neuchâtel, Presses Universitaires Suisses, 2015 .

Kaufmann, Vincent, Les Paradoxes de la mobilité, bouger, s'enraciner, Lausanne, Presses Polytechniques et universitaires romandes, 2017.

Kopinak, Kathryn, “Types of Migration Enabled by Maquiladoras in Baja California, Mexico: The Importance of Commuting”, The Journal of Borderlands Studies, Vol. 28, n¹, 2013, 75-91.

Lapeyrouse L.M., et al, "A Profile of US-Mexico Border Mobility Among a Stratified Random Sample of Hispanics Living in the El Paso-Juarez Area", The Journal of Migrant and Minority Health, 2012, 14(2): 264271.

Levy, Jacques, Dictionnaire de géographie et de l'espace des sociétés, 2013.

Macias, Marie-Carmen, «L'Espace frontalier Mexique/États-Unis après le 11 septembre 2001 : Entre processus transfrontaliers et transnationaux », Cahiers des Amériques latines, 56 | 2007, 83-97.

Macias, E.P. and Morales, L.S., "Crossing the Border for Health Care”, Journal of Health Care for the Poor and Underserved, 2001, 12(1): 77-87.

Martinez, Oscar, "Transnational Fronterizos: Cross-Border Linkages in Mexican Border Society”, The Journal of Borderlands Studies, 5:1, 1990, 79-94.

McGuire, Randall H., "Steel Walls and Picket Fences: Rematerializing the U.S.-Mexican Border in Ambos Nogales", The American Anthropologist, Volume 115, Issue 3, September 2013, pp 466-480. 
Miller-Thayer, Jennifer, "Health Migration: Crossing Borders for Affordable Health Care", Field Actions Science Reports [Online], Special Issue 2|2010, http://journals.openedition.org/factsreports/503 (accessed August 28, 2019).

Montulet, Bertrand, Hubert, Michel, Jemelin, Christophe and Schmitz, Serge, Mobilités et temporalités, Bruxelles, Publications des Facultés universitaires Saint Louis, 2005.

Oberle, Alex P. and Arreola, Daniel, "Mexican medical border towns: A case study of Algodones, Baja California", The Journal of Borderlands Studies, Vol 19, Issue 2, 2004, pp. 27-44.

O'Toole, Molly, "Trump ordered 15,000 new border and immigration officers - but got thousands of vacancies insead", Los Angeles Times, January 27, 2019. https://www.latimes.com/politics/la-na-pol-border-patrol-hiring20190126-story.html (Accessed January 30th, 2020)

Popescu, Gabriel, Bordering and Ordering the Twenty-first Century: Understanding Borders, Lanham, Rowan and Littlefield, 2012.

Pradeau, Christian, Jeux et enjeux des frontières, Bordeaux, Presses universitaires de Bordeaux, 1994, p. 235.

Renard, Jean-Pierre and Gay, Jean Christophe, Les discontinuités spatiales. In : Hommes et Terres du Nord, 1995.

Revel-Mouroz, Jean, "Perméabilité de la frontière Mexique-Etats-Unis. La mobilité des consommateurs, des travailleurs et des entreprises", Bulletin de l'Association des Géographes Français, 1980, pp. 227-234.

Sands, Christopher, Toward a New Frontier: Improving the U.S.-Canadian Border, Brookings, Metropolitan Policy Program, 2009.

Schuler, M. et al, Eine Integrative Sicht der Mobilität: Im Hinblick auf ein neues Paradigma der Mobilitätsforschung, Bern: Schweizerischer Wissenschaftsrat, 1997.

Sheller, Mimi and Urry John, "The New Mobilities Paradigm” in Environment and Planning A, February 2006, volume 38, pages 207-226.

Sullivan, Pauline et al, "Mexican National Cross-Border Shopping: Exploration of Retail Tourism", The Journal of Retailing and Consumer Services, vol. 19(6), 2012, pp. 596-604.

Tapia, Marcela, "Las fronteras, la movilidad y lo transfronterizo: Reflexiones para un debate", in Estudios fronterizos, 18 (37), 2017, 61-80.

Tréguer, Annick, "Entre Mexique et Etats-Unis: Laredo, ville frontière", in Revue Française d'Etudes Américaines, La Mexicanité aux Etats-Unis, nº6, Novembre 1995, 528-533.

Van der Velde, Martin and Spierings, Bas, "Consumer mobility and the communication of difference: Reflecting on cross-border shopping practices and experiences in the Dutch-German borderland", The Journal of Borderlands Studies, Vol 25, Issue 3-4, 2010, pp. 191-205.

Vanneph, Alain (a), «Mexique/États-Unis : identités frontalières », Territoire, Lien ou frontière ?, 1995, http://horizon.documentation.ird.fr/exl-doc/pleins_textes/divers08-09/010014865-44.pdf_accessed on November $15,2018)$

Vanneph, Alain (b), «Villes frontalières Mexique-États-Unis » in Gondard Pierre (dir), La Frontière Mexique/États-Unis - Mutations économiques, sociales et territoriales, Paris, Édition de l'IHEAL, 1995. 


\section{Websites}

Arizona Demographics, "Is Nogales the best Arizona city for your business?”, 2019, < $\underline{\text { https://www.arizona- }}$ demographics.com/nogales-demographics> (accessed on August 5, 2019).

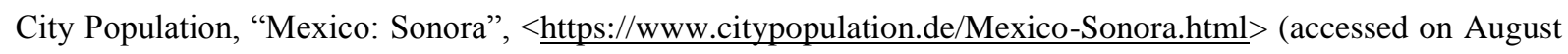
6, 2019).

Economic and Business Research Center, "Border Crossings, Nogales", Arizona-Mexico Economic Indicators, 2019, <https://azmex.eller.arizona.edu/border-crossings/border-crossings-arizona-bpoe/border-crossingsnogales> (accessed on June 14, 2019).

US Census Bureau, "QuickFacts - Nogales city, Arizona”, Washington DC, US Census Bureau, < https://www.census.gov/quickfacts/fact/table/nogalescityarizona/IPE120217> (Accessed on August 5, 2019).

US Trade Numbers, "Mexico”, 2019, <https://www.ustradenumbers.com/country/mexico/> (accessed on August 6, 2019).

\section{Interviews}

Interview with Bruce Bracker, Supervisor District \#3, Santa Cruz County, April 30, 2019.

\section{Tables with caption (indiv pages)}

Table 1: Schuler's typology on mobility

\section{Figure caption (as a list)}

Figure 1: Frequency of border-crossing

Figure 2: Places of origins of the respondents

Figure 3: Distance from the border according to frequency of border crossing

Figure 4: Reasons for crossing according to distances

Figure 5: Reasons for crossing according to age categories

Figure 6: Survey that the participants answered

\section{Table 1 : Schuler 1997}

Shuler's typology on mobility

\begin{tabular}{|l|l|l|}
\hline & Short term & Long term \\
\hline $\begin{array}{l}\text { Inside a } \\
\text { living area }\end{array}$ & $\begin{array}{l}\text { Same-day travel/day- } \\
\text { to-day displacement }\end{array}$ & Residential mobility \\
\hline $\begin{array}{l}\text { Outside a } \\
\text { living area }\end{array}$ & $\begin{array}{l}\text { Travel (Tourism and } \\
\text { Business) }\end{array}$ & $\begin{array}{l}\text { Migration } \\
\text { (international and } \\
\text { regional) }\end{array}$ \\
\hline
\end{tabular}

\section{Figure 1 :}




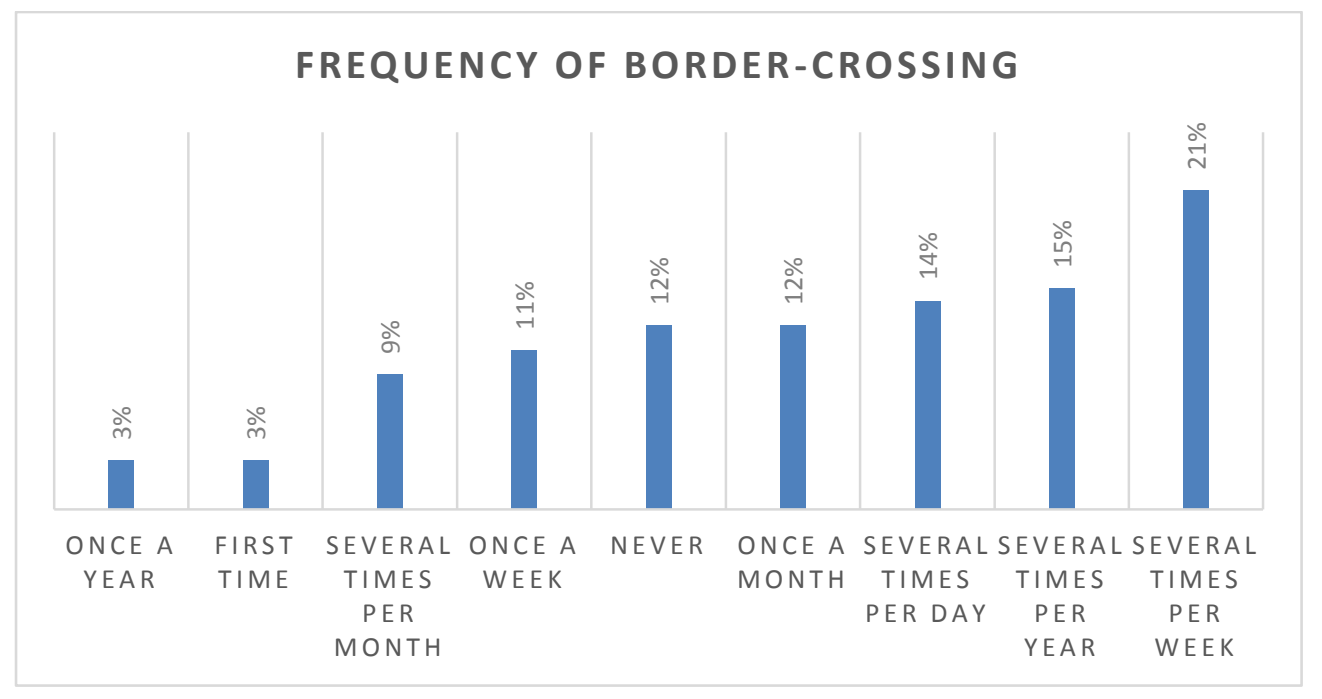

Source : Developed by the authors

\section{Figure 2 :}

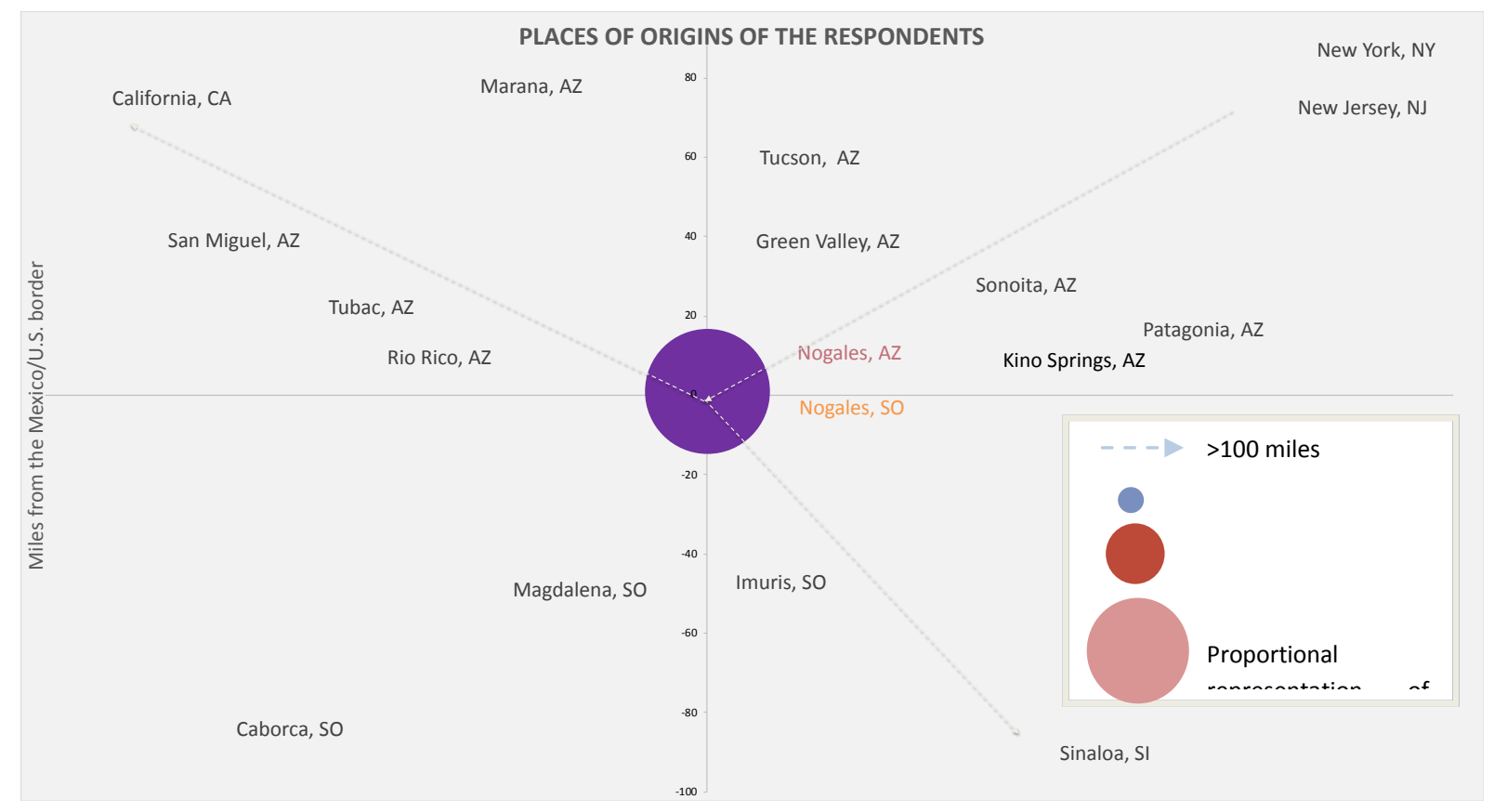

Source : Developed by the authors

\section{Figure 3 :}




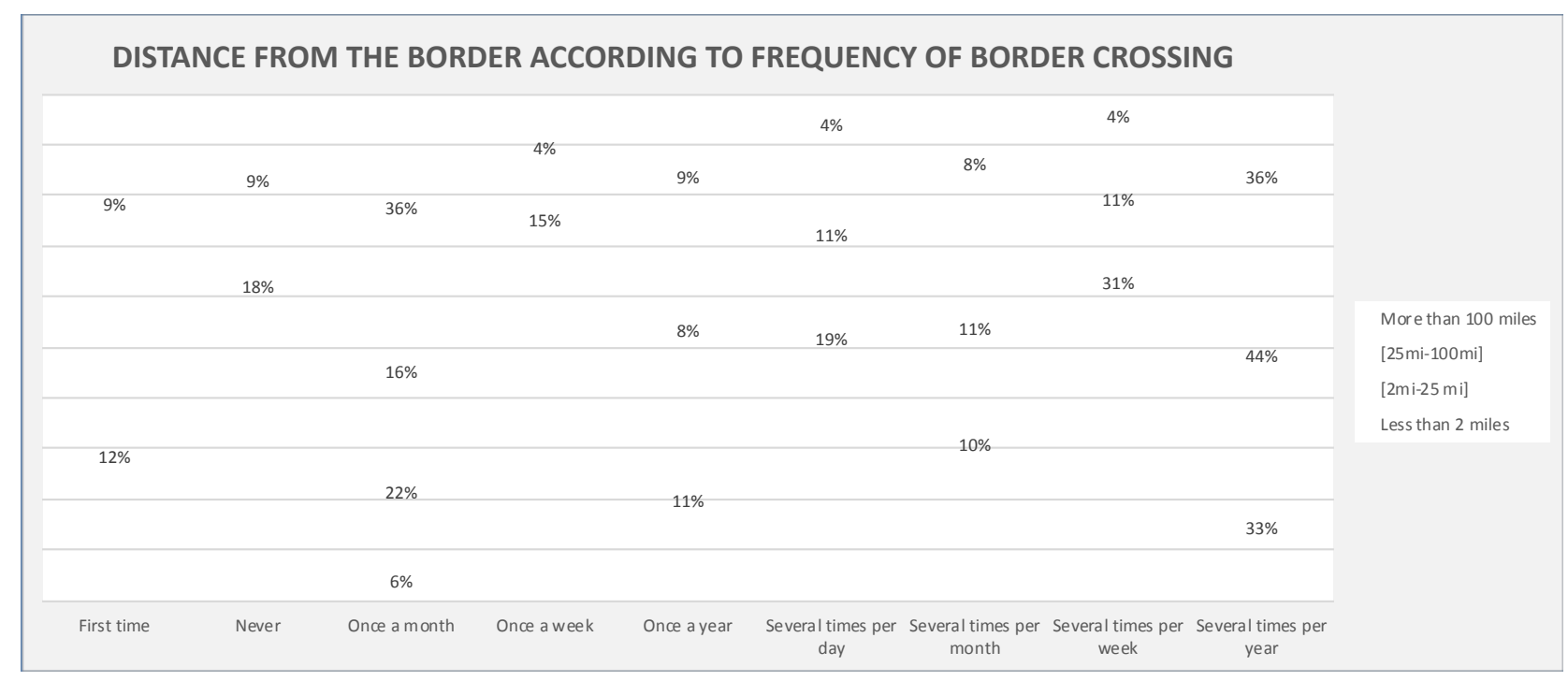

Source : Developed by the authors

\section{Figure 4 :}

\section{REASONS FOR CROSSING ACCORDING TO DISTANCES}

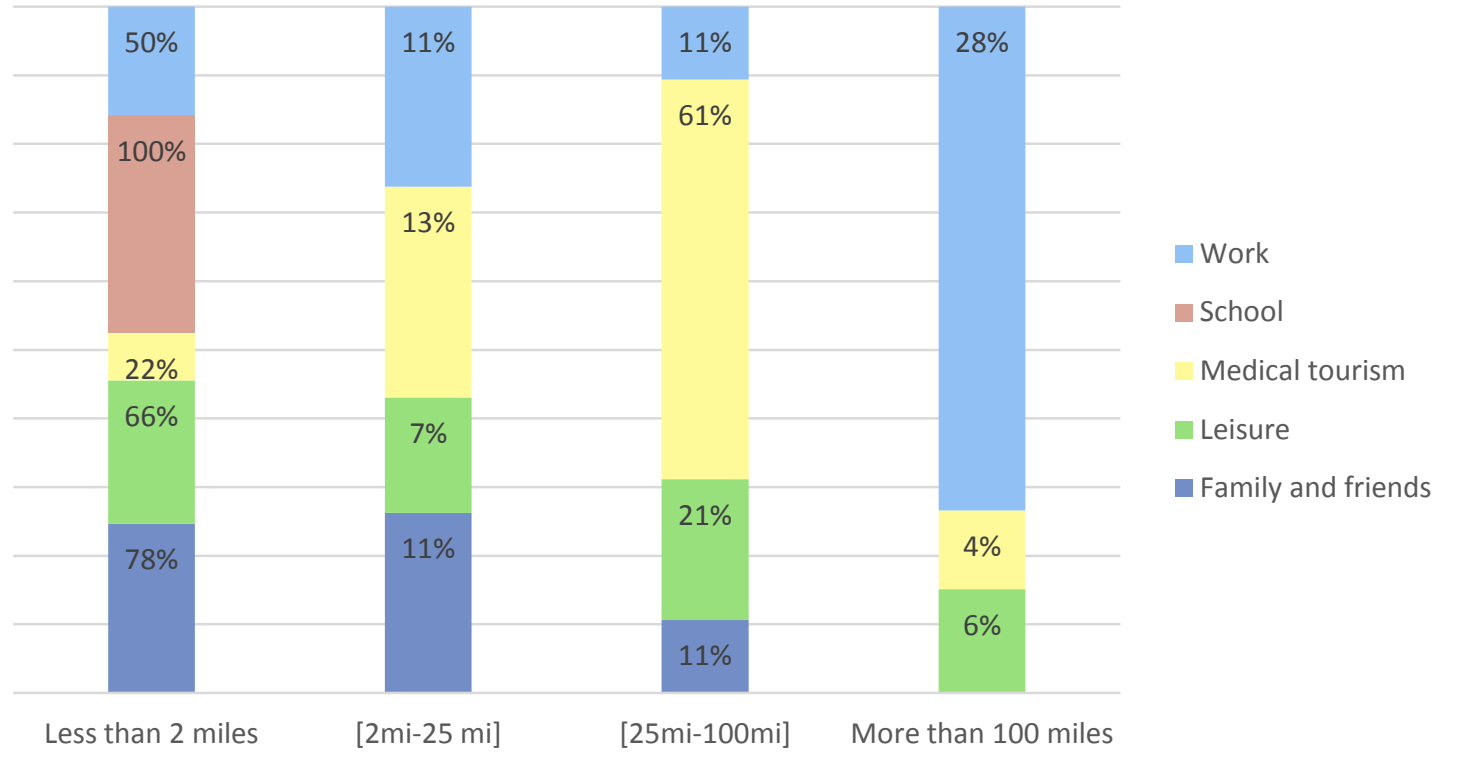

Source : Developed by the authors 


\section{Figure 5 :}

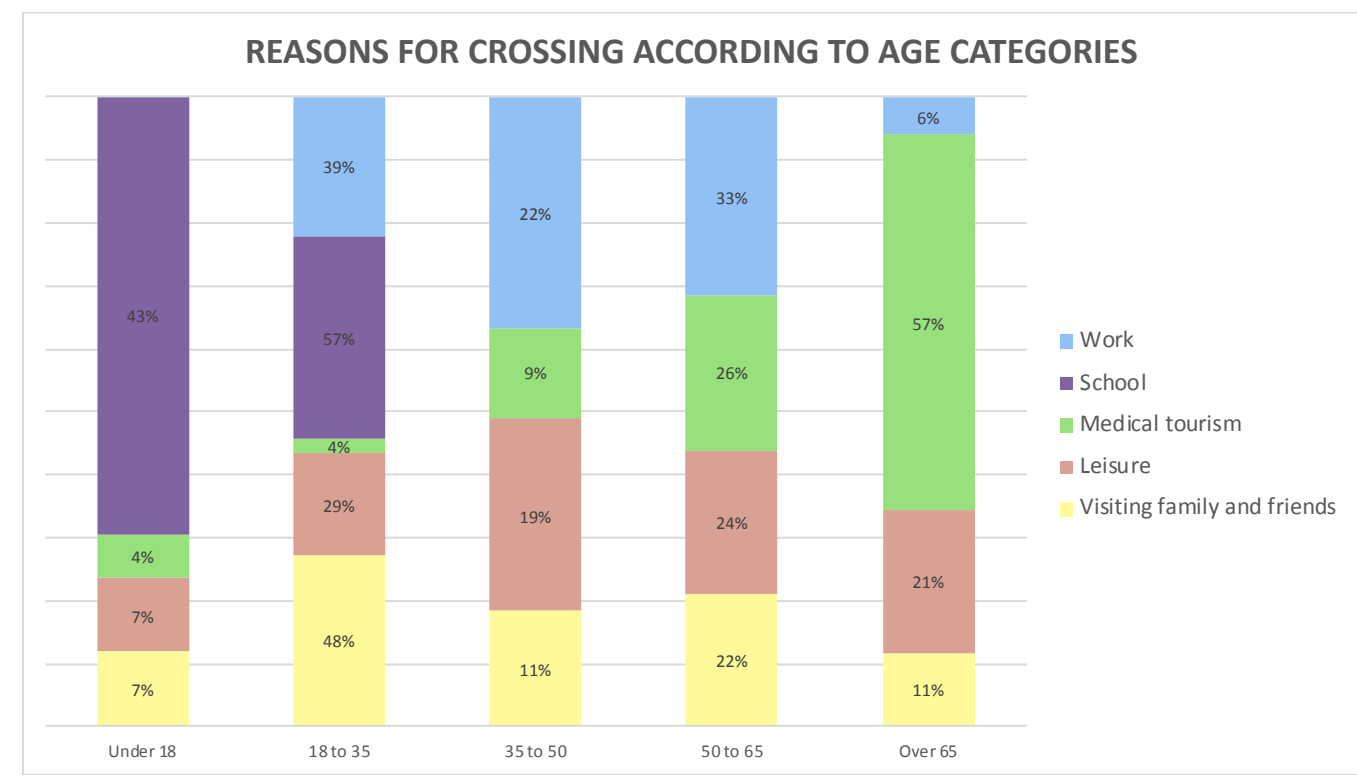

Source : Developed by the authors

Figure 6

Figure 6 : Survey that the participants answered

\begin{tabular}{|ll|l|}
\hline \multicolumn{2}{|c|}{ Ended questions } \\
\hline 1) & Gender & Male/ female/ other \\
\hline 2) & Age & Under 18/18-35/35-50/ 50-65/ over 65 \\
\hline 3) & $\begin{array}{l}\text { Distance of the living place from the } \\
\text { border: how far from the border do } \\
\text { you live? }\end{array}$ & $\begin{array}{l}\text { Less than 2 miles/ between } 2 \text { and } 5 \text { miles/ } \\
\text { more than } 10 \text { miles }\end{array}$ \\
\hline 4) & $\begin{array}{l}\text { Frequency of border crossing: how } \\
\text { often do you cross the border? }\end{array}$ & $\begin{array}{l}\text { Several times per week/ several times per } \\
\text { year/ several times per day/ several times } \\
\text { per month/once a month/once a week/once a } \\
\text { year/first time/never }\end{array}$ \\
\hline
\end{tabular}




\begin{tabular}{|c|c|c|}
\hline & $\begin{array}{l}\text { Modes of transportation: how do you } \\
\text { cross? }\end{array}$ & On foot/ by car/ both/bike \\
\hline 6) & $\begin{array}{l}\text { Reasons for crossing the border: why } \\
\text { are you crossing the border? }\end{array}$ & $\begin{array}{l}\text { Leisure (shopping, restaurants, bars, food, } \\
\text { for the fun)/ visit family and friends/ medical } \\
\text { reasons/for work/ for school }\end{array}$ \\
\hline 7) & $\begin{array}{l}\text { Are you a member of a facilitation } \\
\text { program? If so, which one? }\end{array}$ & Yes (type of facilitation program)/ no \\
\hline \multicolumn{3}{|c|}{ Open questions } \\
\hline 8) & \multicolumn{2}{|l|}{ Where do you live (city)? } \\
\hline 9) & \multicolumn{2}{|c|}{$\begin{array}{l}\text { Has Donald Trump's election altered your interaction with the border? If so, explain } \\
\text { why in what ways. }\end{array}$} \\
\hline
\end{tabular}

